\title{
DOCUMENTS
}

Acts of General Assembly

Affidavits

Approval by Executive Council of Investigation of Agricultural College Funds

Checks (see list)

Deeds

Distribution of $5 \%$ School Fund

List of lots at Iowa City

Opinions of Attorney General

Release of Railroad Lands

Statements

Banks

Bond agents

State Treasurer

'Transcripts

Unclassified

\section{SIR RICHARD .COBDEN LECTURES AT DUBUQUE}

Yesterday Sir Richard Cobden, the sturdy English champion of reform, paid our city a visit. He was on the road from Chicago to St. Louis. During his stay here he was the guest of Rufus Spaulding, Esq. In company with several of our citizens he visited some of our city schools, with which he was most highly delighted, expressing himself astonished at the perfection to which our school system had attained, and farther, that such a system could never succeed in England, or on the Continent generally owing to the predominance of secular despotic influence. He made a few remarks at the city high school which are said to have been brim full of good sense. Sir Robert has arrived at middle age, is some five feet ten, florid, open countenance, and a portly figure of a genuine John Bull. He seems, like Greeley, to be always intently thoughtful and listens to one's remarks with an earnestness almost painful in its intensity. His conversation is deliberate, impressive, exact, and is expressed in pure rugged Saxon. He complimented the present condition of the West and spoke cheeringly of its future. He left yesterday afternoon for St. Louis on the War Eagle.-Dubuque Express and Herald, March 26, 1859. (In the Newspaper Collection of the Historical, Memorial and Art Department of Iowa.) 
Copyright of Annals of Iowa is the property of State of Iowa, by \& through the State Historical Society of Iowa and its content may not be copied or emailed to multiple sites or posted to a listserv without the copyright holder's express written permission. However, users may print, download, or email articles for individual use. 